\title{
Real wage responsiveness to unemployment in Spain: asymmetries along the business cycle
}

\author{
Paulino Font ${ }^{*}$, Mario Izquierdo and Sergio Puente
}

\author{
* Correspondence: \\ paulino.fontg@gmail.com \\ Department of Economic Analysis \\ and Forecasting, Banco de España, \\ Madrid, Spain
}

\begin{abstract}
We estimate real wage cyclicality in the period compressed between 1987 and 2013 using a large administrative dataset of workers in Spain. Real wages are weakly procyclical in Spain and focusing on differences in different phases of the business cycle, we find that differences across expansions and recessions are significant, with an even lower real wage cyclicality in recessions. Furthermore, higher levels of unemployment do not translate into additional real wages adjustments when the economy is contracting, while lower levels of unemployment during expansions have incremental effects on wage elasticity. This general result holds after accounting for differences in tenure, type of contract and age categories.

Nevertheless, wages of newly-hired workers are the most sensitive to the business cycle and exhibit the lowest asymmetric pattern between expansions and recessions. At the other end, wages of workers with more than six years of tenure can be characterized as the most protected against economic downturns. The same is true for fixed-term vs. permanent workers, as well as for young vs. older workers.

JEL classification: e32, j31

Keywords: Wage cyclicality; Downward wage rigidity; Social security data
\end{abstract}

\section{Introduction}

Wage reaction to the crisis initiated in 2008 is in the core of the economic and political debate. This is especially so in Euro Area countries like Spain, where unemployment has more than tripled since 2008, while wages, at least in the initial phase of the crisis, failed to react to the strong deterioration of the labor market, and a rise in real wages was observed ${ }^{1}$.

However, the empirical literature on wage responsiveness to the economic cycle tends to be inconclusive. Studies based on aggregate data tend to fail in finding a procyclical pattern in real wages for most countries, since changes in the composition of the work force induce a countercyclical bias in the aggregate real wage (Mitchell et al. 1985, Solon et al. 1994, for instance). On the other hand, studies based on micro data show a much clearer procyclical behavior of real wages (Shin 1994 and Devereux 2001, for instance). In addition, when worker's heterogeneity is taken into account, the procyclical pattern that wages exhibit tends to be more pronounced for newlyhired employees, while wages of incumbent workers are found to be more rigid (Carneiro et al. 2012, for instance). In the case of Spain, mostly due to the absence of individual databases to properly estimate wage elasticity to labor market conditions, 
the empirical evidence is scarce. A recent exception is De la Roca (2014), who uses Social Security Registers information to estimate wage elasticity to unemployment variation controlling for individual heterogeneity. In his study, De la Roca finds weak procyclicality of real wages in Spain, estimating that a one percentage point decline in the unemployment rate increases real wages by $0.4 \%$. This estimate is considerably lower than the ones estimated for developed countries. In Pissarides (2009), for instance, elasticities are shown to be higher than 1 in most studies covering US and some European labor markets.

In this paper, we follow a similar approach to De la Roca (2014), although we focus on how wage cyclicality varies during the different phases of the business cycle. Theoretically, there are multiple reasons to expect an asymmetric response of wages to the prevailing economic conditions, downward adjustments being much more difficult in the presence of nominal and/or real downward wage rigidities, which are extensively documented in the literature (Dickens et al. 2007). However, empirical evidence of differences along the business cycle is neither abundant nor conclusive. For instance, Cervini et al. (2013), using BHPS data for UK find that wage cyclicality is considerably higher in economic recessions, and Martins (1997) finds similar results for Portugal. On the contrary, Shin and Shin (2008), for the US, finds the opposite result, that is, wage cyclicality is higher during expansionary periods. As far as we are aware, we present the first empirical results regarding the Spanish labor market in this respect.

The rest of the paper is structured as follows. In section 2, we provide a brief description of the dataset. Section 3 discusses the methodology implemented. Section 4 presents our estimated results. Final remarks are then presented in Section 5.

\section{Dataset}

In this study, we make use of Spain's Social Security Administrative Labor Records (Muestra Continua de Vidas Laborales, MCVL hereinafter), which records the employment histories of a $4 \%$ non-stratified random sample of workers registered in the social security system at some point between 2005 and 2013. For these workers, the MCVL records all labor market transitions and job characteristics since 1980 or since first appearance in the social security system. The high frequency of our data ${ }^{2}$ allows us to properly track labor market transitions, many of which would go unnoticed in lower frequency datasets. Altogether, with the reliability of the information provided ${ }^{3}$, the MCVL is a desirable longitudinal dataset to study wage responses to the cycle from a microeconomic point of view.

To estimate wage cyclicality, we focus on the evolution of wages of salaried workers in the private sector and exclude therefore self-employment and public administration employees. Our wage variable records daily real wages in 2011 prices $^{4}$ for those workers that reported at least seven days of fulltime work in a given month. In this dataset, wages are proxied by the Social Security contribution base. For most workers, this is exactly equal to the earned wage. However, the existence of an upper bound in the Social Security contribution base makes it impossible to know the exact wage for the top part of the distribution. Hence, salaries are right-censored for some individuals. We present estimates of the cyclicality excluding right-censored wages, but our results are not affected if we include them in the dataset ${ }^{5}$.

To account for differences of wage response among different job tenure categories, we construct a variable that reflects worker's tenure by accumulating the days worked 
in a firm. A worker starts a new job from either unemployment or inactivity or from an employment to employment transition (switches firms). The former is classified as newly-hired, and the latter as a job mover. A worker will either be recorded as newlyhired or as a job mover within the first year in the firm. After that first year, our job tenure categories comprise 1-2 years of work in the firm, 2-4 years, 4-6 years, and 6 or more years ${ }^{6}$. Given the high frequency of our data, it is possible to observe multiple transitions from employment to unemployment in a given calendar year by a single worker within the same firm. In this case, we will maintain the worker's accumulated experience as long as the worker's separation from the firm does not expand beyond 11 months and as long as the worker does not switch firms before returning. If the worker either switches firms or returns after 12 months or later, her accumulated working experience in the firm resets to zero. Table 1 presents main characteristics of our database, including more than 12 million observations on a monthly basis from $1987^{7}$ to 2013 for some 163,000 workers. As it can be seen in this Table, the composition of the workforce across tenure categories shows around one quarter of workers in the group of higher tenure (more than 6 years), while around $30 \%$ of workers are either newly-hired or job movers.

\section{Methodology}

The empirical model we use to analyze real wage cyclicality is a monthly level wage equation with individual fixed effects. The introduction of workers fixed effects is needed to address the workforce composition bias that originates along the different phases of the business cycle (Solon et al. 1994). Most commonly, previous studies have estimated a first differences wage regression model to address such composition bias (Solon et al. 1994, Shin 1994, Devereux 2001). However, since we also want to estimate

Table 1 Distribution of observations (a)

\begin{tabular}{llllll}
\hline & Total & $\begin{array}{l}\text { Recession } \\
\text { Unemp. High }\end{array}$ & $\begin{array}{l}\text { Expansion } \\
\text { Unemp. High }\end{array}$ & $\begin{array}{l}\text { Expansion } \\
\text { Unemp. Low }\end{array}$ & $\begin{array}{l}\text { Recesion } \\
\text { Unemp. Low }\end{array}$ \\
& & $\mathbf{( 1 )}$ & $\mathbf{( 2 )}$ & $\mathbf{( 3 )}$ & $\mathbf{( 4 )}$ \\
\hline New hires & 17.7 & 13.7 & 20.4 & 18.8 & 15.4 \\
Job movers & 13.1 & 8.2 & 11.4 & 16.3 & 11.0 \\
Tenure 1-2 & 14.3 & 11.6 & 13.9 & 15.4 & 15.4 \\
Tenure 2-4 & 17.6 & 18.2 & 15.5 & 17.7 & 19.8 \\
Tenure 4-6 & 10.9 & 13.8 & 9.9 & 10.1 & 11.0 \\
Tenure 6+ & 26.4 & 34.4 & 28.9 & 21.7 & 27.5 \\
Permanent & 68. & 78.6 & 70.6 & 62.9 & 74.2 \\
Fixed-term & 31.1 & 21.4 & 29.4 & 37.1 & 25.8 \\
16-29 & 27.6 & 18.2 & 32.3 & 30.6 & 24.3 \\
30-45 & 46.8 & 51.1 & 44.7 & 45.3 & 49.0 \\
45+ & 25.6 & 30.7 & 23.0 & 24.1 & 26.8 \\
Number of observations & $12,473,369$ & $2,716,514$ & $2,340,325$ & $6,203,384$ & $1,213,146$ \\
(First stage) & & & & & \\
Number of individuals & 163,447 & 99,295 & 76,317 & 138,472 & 94,739 \\
(First stage) & & & & & \\
\hline
\end{tabular}

(a) Calculated from a $20 \%$ random sample of the MCVL. Share in sample (\%). 
the wage cyclicality for those workers moving from non-employment to employment, we make use of a wage equation in levels ${ }^{8}$. Our model's baseline specification is

$$
\ln \omega_{i m}=\alpha_{i}+X_{i m} \beta+\zeta_{0} U_{t-4}+\gamma_{0} m+\gamma_{1} m^{2}+e_{i m}
$$

where $\omega_{i m}$ is the real daily earnings of individual $i$ in month $m, X_{i m}$ is a vector of timevarying individual and job type characteristics that include the age, the square of the age, the worker's job tenure category, the type of contract, a proxy for education (the worker's social security contribution group), and sector dummies. In addition, a linear time trend $m$ and its square are included. $U_{t-4}$ is our cycle variable: The level of the aggregated unemployment rate experienced by the economy in quarter $t-4{ }^{9}$. Finally, $e_{i m}$ is a zero mean random term with constant variance.

Since all workers in month $m$ are exposed to the same level of unemployment, the standard error of the coefficient of interest $\zeta_{0}$ would be underestimated in the presence of time-specific errors (Moulton 1986). As in De la Roca (2014), we follow Solon et al. (1994) and Devereux (2001), adopting a two-step estimation procedure to overcome this problem. Our new specification is described in the following equations:

$$
\begin{aligned}
& \ln \omega_{i m}=\alpha_{i}+X_{i m} \beta+\sum_{t=1}^{T} \kappa_{t} D_{t}+\varepsilon_{i m} \\
& \widehat{\kappa}_{t}=\mu U_{t-4}+\partial_{1} t+\partial_{2} t^{2}+\sum_{t=1}^{4} \varphi_{t} q_{t}+v_{i t}
\end{aligned}
$$

Equation 2 incorporates a set of dummy variables $D_{t}$ that reflect year-quarter combinations ${ }^{10}$. The estimated coefficients $\widehat{\kappa}_{t}$ capture variations in wages that are free from observed characteristics and time-invariant unobserved individual heterogeneity. These coefficients are then regressed against the unemployment rate, a linear time trend and its square, and seasonal dummies (equation 3). The standard error of the semielasticity of real wages to the unemployment rate $\mu$, is now free from the grouped or aggregated bias present in equation (1). As our cyclical variable is the level of the unemployment rate, a negative estimate value of $\mu$ would imply that real wages are procyclical, while counter-cyclicality of wages would be indicated by a positive value.

Insofar as we are interested in tracking down asymmetries along the business cycle, we divide periods in which the economy is expanding (measured by positive employment growth on a year-on-year basis) from those periods that the economy is contracting (negative employment variation) ${ }^{11}$. Moreover, we further divide periods according to the unemployment rate level being above or below the mean of the whole period considered (1987-2013). This distinction allows us to check, for instance, whether if downward pressure on wages when employment is falling is more intense after a long recession-when unemployment is also high-or not. In principle, there are different reasons to think this would be the case if, for example, a long recession has left the economy with a large stock of unemployed workers posing extra pressure on wage adjustment. However, the opposite could be true if, for example, the composition of the unemployment rate is biased towards a high percentage of long-term unemployed (possibly less attached to the labor market), resulting in a lower downward pressure on wages. 
In other words, we divide the business cycle in four phases. The first one consists of an economy in recession (employment is falling) and with a high level of unemployment (above the historical average); in the second phase, the employment starts to rise, but the economy still experiences high levels of unemployment. The third phase would consist of an expanding economy that enjoys low levels of unemployment; and finally, in the fourth phase, the economy enters into recession but still maintains a low unemployment rate.

In Figure 1, we present the actual evolution of employment growth and unemployment rate in Spain since 1987. The vertical axis is plotted at the average unemployment rate across all the period (16.7\%). Hence, the four sub-periods defined above correspond to the four quarters in the graph. The natural movement in such a graph is in counterclockwise circles, and a complete circle represents a complete business cycle.

The chart represents two complete business cycles. Commenting only on the most recent, high unemployment levels coexisted with incipient positive employment growth rates at the end of 1994. This situation lasted until the beginning of the 2000s (phase 2 in the above definitions, corresponding to the top-right quarter in the graph). Then, unemployment started to lie below its average (phase 3, top-left quarter). This expansionary period lasted until the end of 2007, with a decreasing unemployment rate below the historical average. The recession initiated in 2008 with a marked decrease in employment, although the unemployment rate was still below the average until the beginning of 2010 (phase 4, bottom-left quarter). Finally, the continuing deterioration in the labor market brought the unemployment rate above its average until the end of the sample period (phase 1, bottom-right quarter).

\section{Empirical results}

Before presenting our estimated results of real wage cyclicality, it is worth presenting some of the main characterizing features of the wage setting in Spain over the period 1987 to 2013. Firstly, collective agreements cover about $90 \%$ of the salaried workforce in the private sector, despite relatively low unionization levels, due the automatic

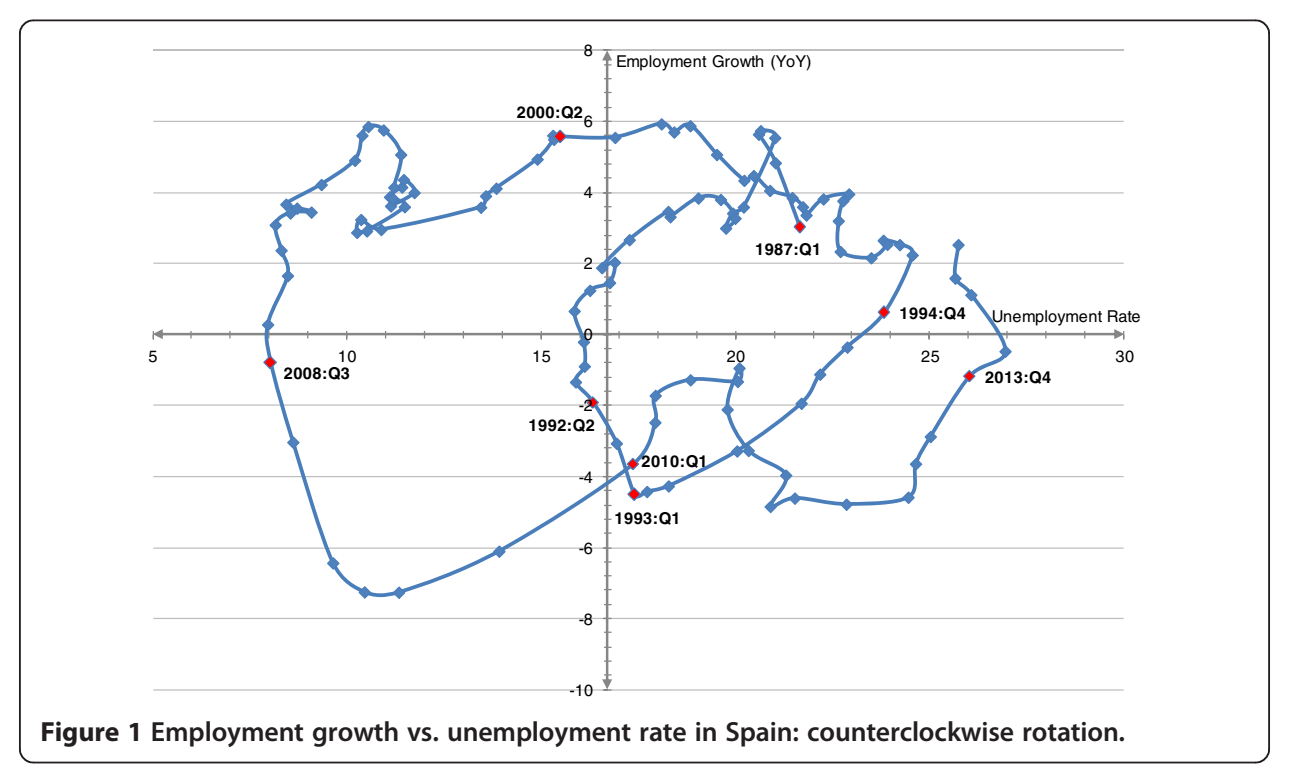


extensions of collective agreements. Collective agreements are mainly bargained at the province-sector level, with a very low share of firm-level agreements. This predominance of negotiations at an intermediate level of decentralization has been found to provide a low association of wages and labor conditions to firms' individual performance (See, for instance, Bentolila et al. 2010 and Izquierdo et al. 2004). Recent labor market reforms have indeed tried to increase the decentralization of the collective bargaining system in Spain, although it is still not possible to assess the impact of these reforms on wage cyclicality. Moreover, traditionally, the Spanish labor market has been characterized by a strong wage indexation to inflation, resulting in a high inertia of wages and real downward wage rigidities (Messina et al. 2010).

Table 2 depicts the estimates of our two-step equation model, showing real wage semi-elasticity to unemployment variations along the four business cycle phases defined previously $^{12}$. The first thing to notice is that, regardless of what phase the economy is in, real wages are very weakly procyclical in Spain. Our estimates point to an increase (decrease) of between 0.24-0.48 pp in real wages after a decrease (increase) of $1 \mathrm{pp}$ in the unemployment rate. These estimates are similar to those reported by De la Roca (2014) for the Spanish case when no differences across the business cycle phases are allowed, and they are much lower than those found for other countries. For instance, Pissarides (2009) summarizes the evidence of real wage cyclicality in the US and some European countries, finding wage to unemployment semi-elasticities being above 1 in the US case, although with large differences between job-movers and job-stayers. Results for different European countries also tend to find this semi-elasticity above 1, especially in the UK (close to 2 according to Devereux and Hart (2006) and Peng and Siebert (2006)), but also in Germany, Italy or Portugal ${ }^{13}$.

On top of this low wage sensitivity to business cycle conditions, we also find significant differences depending on the cyclical phase of the economy. That is, wage cyclicality in Spain does not exhibit a symmetric pattern along the business cycle, and wages respond differently depending on what phase of the cycle the economy is operating in.

In particular, looking at the results shown in Table 2, downward wage rigidities seem to be playing a relevant role in the Spanish labor market, as wage cyclicality is much lower in recessions than in expansions, and the level of the unemployment rate appears to be relevant only in expansionary periods. These results are in line to those reported by Shin and Shin (2008) for the US, although in that case, no distinction was made according to the level of the unemployment rate.

More specifically, if we analyze how wage cyclicality varies along the four phases defined in this paper, Column 2 would describe how wages are related to unemployment variations in a recovery phase, like the situation in Spain in 2014, where employment is

Table 2 Real wage cyclicality: 4 scenarios

\begin{tabular}{lllllllll}
\hline & Recession & & Expansion & & Expansion & \multicolumn{3}{l}{ Recesion } \\
& Unemp. high & Test & Unemp. high & Test & Unemp. low & Test & Unemp. low & Test \\
& $(\mathbf{1})$ & $\mathbf{1 = 2}$ & $\mathbf{( 2 )}$ & $\mathbf{2 = 3}$ & $\mathbf{( 3 )}$ & $\mathbf{3 = 4}$ & $\mathbf{( 4 )}$ & $\mathbf{4 = 1}$ \\
\hline Overall & $-0.243^{* * *}$ & $* * *$ & $-0.383^{* * *}$ & $* * *$ & $-0.481^{* * *}$ & $* * *$ & $-0.245^{* * *}$ & no \\
& $(0.038)$ & & $(0.041)$ & & $(0.067)$ & & $(0.065)$ & \\
\hline
\end{tabular}

***Significant at the 1 percent level.

**Significant at the 5 percent level.

*Significant at the 10 percent level.

no: Non-significant. 
starting to grow, but the unemployment rate is still above the historical average. In this situation, wages increase as a response to reductions in the unemployment rate, with a semi-elasticity of $0.38 \%$. If this situation persists, and the expansionary period leads to unemployment falling below its average, the economy would enter in the phase defined by Column 3. In this new phase of higher upward pressure on wages derived from the lower unemployment rate and an increasing level of employment, wage semi-elasticity to unemployment rises to $0.48 \%$. This higher wage sensitivity to the unemployment rate is found to be significantly higher than the one observed under higher unemployment at the $1 \%$ confidence level.

Nevertheless, once the expansionary period ends and the economy starts shrinking, a significantly lower wage reaction to unemployment is found. In particular, a one percentage point increase in the unemployment rate decreases real wages by $0.25 \%$ (column 4). Thus, wage response is almost half that of the one observed in the previous expansionary period, this difference being statistically significant at the $1 \%$ level. Therefore, these results would be coherent with the existence of significant downward wage rigidities in Spain, since wage cyclicality is much lower in recessions than in expansions. Eventually, as the economy continues deteriorating and the unemployment rate keeps rising, the economy moves into a period that combines a worsening economy and a high level of unemployment. Nonetheless, as we can see in Column (1), the semi-elasticity of wages does not experience any variation (remains at $-0.25 \%$ ), and the increasing level of unemployment fails to induce any additional pressure on wages adjustment.

In other words, the semi-elasticity of wages to unemployment when the economy is in recession is low, and it is not found to vary with the unemployment level. When the economy moves out of the recession, real wages are found to show a greater link to business cycle conditions, although lower than in other countries. In these expansionary periods, a low level of unemployment rate is associated with additional wage pressures, while this is not the case in recessionary periods. These results indicate the existence of significant asymmetries in wage formation in Spain, possibly reflecting the impact of the prevailing labor market institutions, such as the interaction between the very high duality between permanent and temporary workers and the prevalence of sectoral levels of negotiations. Overall, this collective bargaining system could be characterized as providing a high level of protection to working conditions of the incumbents or insiders in the labor market, while concerns over the access to a job for those in unemployment are set aside in the bargaining process. As a result, both high levels of unemployment and wage growth can coexist during the first stages of economic recovery, therefore delaying the necessary reduction in unemployment.

In order to fully understand these differences in wage cyclicality across the business cycle and interpret the low wage elasticity observed in Spain with respect to other countries, we next break down differences in wage response to the business cycle for different firm-specific tenure categories. To this end, we interact our six tenure categories with the year-quarter pair dummies in the first stage regression (equation 2 in previous section) and estimate six separate regression models in the second step (equation 3). Estimated results are reported in Table 3.

In this table, we observe that differences across the four cyclical phases defined in this paper are similar across the six tenure categories used. That is, real wage semi- 
Table 3 Real wage cyclicality by tenure groups: 4 scenarios

\begin{tabular}{|c|c|c|c|c|c|c|c|c|}
\hline & \multicolumn{2}{|l|}{ Recession } & \multicolumn{2}{|l|}{ Expansion } & \multicolumn{2}{|l|}{ Expansion } & \multicolumn{2}{|l|}{ Recesion } \\
\hline & Unemp. high & Test & Unemp. high & Test & Unemp. low & Test & Unemp. low & Test \\
\hline & (1) & $1=2$ & (2) & $2=3$ & (3) & $3=4$ & (4) & $4=1$ \\
\hline \multirow[t]{2}{*}{ New hires (a) } & $-0.416^{* * *}$ & $* * *$ & $-0.548^{* * *}$ & $* *$ & $-0.649^{* * *}$ & $* * *$ & $-0.408^{* * *}$ & no \\
\hline & $(0.045)$ & & $(0.048)$ & & $(0.079)$ & & $(0.077)$ & \\
\hline Test $\mathbf{a}=\mathbf{b}$ & no & & no & & no & & no & \\
\hline \multirow[t]{2}{*}{ Job movers (b) } & $-0.333^{* * *}$ & $* * *$ & $-0.484^{* * *}$ & no & $-0.533^{* * *}$ & $* * *$ & $-0.315^{* * *}$ & no \\
\hline & $(0.044)$ & & $(0.047)$ & & $(0.076)$ & & $(0.075)$ & \\
\hline Test $\mathrm{a}=\mathrm{c}$ & no & & no & & no & & no & \\
\hline \multirow[t]{2}{*}{ Tenure 1-2 (c) } & $-0.350^{* * *}$ & $* * *$ & $-0.486^{* * *}$ & $* *$ & $-0.584^{* * *}$ & $* * *$ & $-0.282^{* * *}$ & no \\
\hline & $(0.047)$ & & $(0.051)$ & & $(0.083)$ & & $(0.081)$ & \\
\hline Test $\mathbf{a}=\mathbf{d}$ & $* *$ & & no & & no & & no & \\
\hline \multirow[t]{2}{*}{ Tenure 2-4 (d) } & $-0.274^{* * *}$ & $* * *$ & $-0.456^{* * *}$ & $* * *$ & $-0.599 * * *$ & $* * *$ & $-0.267^{* *}$ & no \\
\hline & $(0.047)$ & & $(0.051)$ & & $(0.083)$ & & $(0.082)$ & \\
\hline Test $\mathrm{a}=\mathrm{e}$ & $* * *$ & & $* *$ & & no & & no & \\
\hline \multirow[t]{2}{*}{ Tenure 4-6 (e) } & $-0.237^{* * *}$ & $* * *$ & $-0.381^{* * *}$ & $* * *$ & $-0.533^{* * *}$ & $* * *$ & $-0.298^{* * *}$ & no \\
\hline & $(0.040)$ & & $(0.043)$ & & $(0.070)$ & & $(0.068)$ & \\
\hline Test $a=f$ & $* * *$ & & $* * *$ & & $* * *$ & & $* *$ & \\
\hline \multirow[t]{2}{*}{ Tenure 6+ (f) } & $-0.130^{* * *}$ & $* * *$ & $-0.253^{* * *}$ & $* * *$ & $-0.333^{* * *}$ & $* * *$ & $-0.134^{*}$ & no \\
\hline & $(0.033)$ & & $(0.036)$ & & $(0.058)$ & & $(0.057)$ & \\
\hline
\end{tabular}

***Significant at the 1 percent level.

**Significant at the 5 percent level.

*Significant at the 10 percent level.

no: Non-significant.

elasticity to unemployment is higher when the economy is expanding and presents low levels of unemployment, regardless of the accumulated experience a worker has within a firm. Similarly, and during recessions, the real wage exhibits a lower elasticity to the unemployment rate evolution, and this downward real wage rigidity seems to be unaffected by the level of unemployment. Again, once the economy initiates its recovery, real wages start increasing again for all tenure categories with a higher sensitivity to our cycle indicator than they showed during recessions. In any case, it should be noted that, as in other countries (Pissarides, 2009, Carneiro et al. 2012), wage cyclicality is found to be higher for newly-hired workers, with point estimates for wage semielasticity ranging from -0.41 (in recessions) to -0.65 in expansionary periods with low unemployment. By contrast, long-tenure workers are found to show very weak wage cyclicality, from -0.13 in recessions to a maximum of -0.33 in expansionary periods. Wage cyclicality estimates are, on a general basis, found to show a monotonic inverse relationship with tenure in the Spanish labor market.

In Table 3, we also present the significance of these differences across tenure categories and to what extent there is some variation across the business cycle. In this regard, differences in wage cyclicality between new-hired, job movers, and low tenure (less than 2 years) workers tend to be non significant, while long-tenure workers tend to exhibit a significantly lower wage sensitivity to unemployment. Interestingly, downward wage rigidities seem to be playing a relevant role protecting wage falls for workers with a tenure higher than two years in the most adverse cyclical situation (recessions with high unemployment), while, by contrast, in expansionary periods only long 
tenure workers (more than 6 years) show a significantly lower wage reaction to unemployment.

Another interesting dimension, although closely related to tenure, is to look at differences in wage cyclicality in Spain by type of contract. The Spanish labor market is characterized by a high level of duality, where a large proportion of the salaried workforce (about 24\% in 2014, but above 30\% over the expansionary period) is under fixed-term contracts with a high turnover rate, while the rest holds over in permanent contracts with high redundancy costs.

Table 4 reflects that wages of workers under fixed-term contracts are more sensitive to the unemployment rate than those wages of workers subject to permanent contracts. In fact, in column (1) we observe that wages of workers under fixed-term contracts are almost two times more responsive to job destruction when the economy is in recession and unemployment is high than wages of workers with a permanent contract $(-0.43$ vs -0.21). Once the economy starts recovering, and despite the existence of a high level of unemployed stock, real wages become more sensitive than they were during the recession for both contract type workers (Column 2), although the increase in the sensitivity is found to be higher for permanent workers. Thus, the wage elasticity in this phase of the cycle is also higher for workers with temporary jobs, but the asymmetry of the real wage response is higher for workers with a permanent job. Once the unemployment rate has lowered and the economy continues expanding (column 3), real wages of permanent workers become even more sensitive to unemployment reductions, while the increase in wage sensitivity of workers with fixed-term contracts is lower. In the next phase (column 4), when the economy enters into recession but still enjoys a low level of unemployed workers, real wages decrease in a less sensitive way for both groups, but more markedly for those with a permanent contract. Overall, as it can be seen in Table 4.A, semi-elasticity of wages to the unemployment rate is statistically higher for those with a temporary contract than for permanent workers, the exception being expansionary periods with low unemployment, when traditionally highly rigid wages of permanent workers show a wage sensitivity to cyclical conditions similar to the one estimated for temporary workers. In other words, asymmetries in wage adjustment between expansions and recessions are clearly higher in Spain among permanent workers, who are especially protected from wage cuts in recessions.

Finally, Table 5 depicts wage semi-elasticity by age groups. We observe that wages of older workers are the most protected from the business cycle in all four phases, while

Table 4 Real wage cyclicality by contract types: 4 scenarios

\begin{tabular}{|c|c|c|c|c|c|c|c|c|}
\hline & Recession & & Expansion & & Expansion & & Recesion & \\
\hline & $\begin{array}{l}\text { Unemp. high } \\
\text { (1) }\end{array}$ & $\begin{array}{l}\text { Test } \\
1=2\end{array}$ & $\begin{array}{l}\text { Unemp. high } \\
\text { (2) }\end{array}$ & $\begin{array}{l}\text { Test } \\
2=3\end{array}$ & $\begin{array}{l}\text { Unemp. low } \\
\text { (3) }\end{array}$ & $\begin{array}{l}\text { Test } \\
3=4\end{array}$ & $\begin{array}{l}\text { Unemp. low } \\
\text { (4) }\end{array}$ & $\begin{array}{l}\text { Test } \\
4=1\end{array}$ \\
\hline \multirow[t]{2}{*}{ Permanent (a) } & $-0.207^{* * *}$ & $* * *$ & $-0.345^{* * *}$ & $* * *$ & $-0.466^{* * *}$ & $* * *$ & $-0.209^{* *}$ & no \\
\hline & $(0.041)$ & & $(0.044)$ & & $(0.071)$ & & $(0.070)$ & \\
\hline Test $a=b$ & $* * *$ & & $* * *$ & & no & & $* *$ & \\
\hline \multirow[t]{2}{*}{ Fixed-term (b) } & $-0.431^{* * *}$ & $* * *$ & $-0.520^{* * *}$ & * & $-0.587^{* * *}$ & $* * *$ & $-0.414^{* * *}$ & no \\
\hline & $(0.043)$ & & $(0.046)$ & & $(0.074)$ & & $(0.072)$ & \\
\hline
\end{tabular}

***Significant at the 1 percent level.

**Significant at the 5 percent level.

*Significant at the 10 percent level.

no: Non-significant. 
Table 5 Real wage cyclicality by age groups: 4 scenarios

\begin{tabular}{|c|c|c|c|c|c|c|c|c|}
\hline & \multicolumn{2}{|l|}{ Recession } & \multicolumn{2}{|l|}{ Expansion } & \multicolumn{2}{|l|}{ Expansion } & \multicolumn{2}{|l|}{ Recesion } \\
\hline & $\begin{array}{l}\text { Unemp. high } \\
\text { (1) }\end{array}$ & $\begin{array}{l}\text { Test } \\
1=2\end{array}$ & $\begin{array}{l}\text { Unemp. high } \\
\text { (2) }\end{array}$ & $\begin{array}{l}\text { Test } \\
2=3\end{array}$ & $\begin{array}{l}\text { Unemp. low } \\
\text { (3) }\end{array}$ & $\begin{array}{l}\text { Test } \\
3=4\end{array}$ & $\begin{array}{l}\text { Unemp. low } \\
\text { (4) }\end{array}$ & $\begin{array}{l}\text { Test } \\
4=1\end{array}$ \\
\hline \multirow[t]{2}{*}{ 16-29 (a) } & $-0.306^{* * *}$ & $* * *$ & $-0.497^{* * *}$ & $* * *$ & $-0.611^{* * *}$ & $* * *$ & $-0.318^{* * *}$ & no \\
\hline & $(0.046)$ & & $(0.049)$ & & $(0.080)$ & & $(0.079)$ & \\
\hline Test $\mathbf{a}=\mathbf{b}$ & no & & $* *$ & & no & & no & \\
\hline \multirow[t]{2}{*}{$30-45$ (b) } & $-0.227^{* * *}$ & $* * *$ & $-0.364^{* * *}$ & $* * *$ & $-0.469^{* * *}$ & $* * *$ & $-0.224^{* * *}$ & no \\
\hline & $(0.037)$ & & $(0.040)$ & & $(0.065)$ & & $(0.063)$ & \\
\hline Test $\mathrm{a}=\mathrm{c}$ & $* * *$ & & $* * *$ & & $* * *$ & & * & \\
\hline \multirow[t]{2}{*}{$45+(c)$} & $-0.146^{* * *}$ & $* * *$ & $-0.264^{* * *}$ & $* * *$ & $-0.353^{* * *}$ & $* * *$ & $-0.146^{*}$ & no \\
\hline & $(0.035)$ & & $(0.037)$ & & $(0.061)$ & & $(0.060)$ & \\
\hline
\end{tabular}

***Significant at the 1 percent level.

**Significant at the 5 percent level.

*Significant at the 10 percent level.

no: Non-significant.

wages of workers aged 16 to 29 years old are the most affected by changes in the unemployment rate. For all age group categories, we observe that wages are more sensitive to expansions than they are to recessions. Furthermore, a higher unemployment rate does not statistically affect the path at which real wages adjust during a recession, while the opposite is true with a lower unemployment rate when the economy is expanding. This is, in fact, a clear example of downwardly rigid wages.

All in all, the estimations for different groups suggests a lower wage semi-elasticity (especially in recessions) for those groups more protected from unemployment (permanent, older, and high tenured). Regarding firm's characteristics, the information available in our database is limited. By firm's size, no significant differences in wage cyclicality are found, while by sectors of activity, wages in the construction sector are found to be additionally downwardly rigid in Spain in recessionary periods, while no significant differences are found in upturns ${ }^{14}$.

\section{Conclusions}

In this paper, we have carried out an analysis of the wage cyclicality in Spain accounting for worker heterogeneity. Our results show that real wages are very weakly procyclical, showing a much lower association with the cyclical conditions in the labor market than is observed in other European countries. Moreover, wage sensitiveness to unemployment is not constant along the business cycle. In fact, real wages are found to be more sensitive to unemployment decreases during expansionary periods, while downward wage rigidities pose limits to wage adjustments in recessions. Furthermore, the level of unemployed stock in the economy seems not to affect the path at which real wages adjust during an economic downturn, but low levels of unemployed individuals lead to higher procyclicality of real wages in a booming economy.

This general picture remains unchanged when we look at differences between different types of workers, in particular, across tenure categories, contract type, and age groups. We show that wage procyclicality is lower for high tenured individuals, those with a permanent contract, and older workers, who also present a higher asymmetry in wage cyclicality between expansions and recessions. As a result, these workers are 
especially protected against wage adjustments in economic downturns, while during expansionary periods these differences tend to disappear.

All in all, these results point to very low wage cyclicality in Spain with respect to those usually estimated for the US and other European countries. We also found an important role of downward wage rigidities limiting wage reductions in recessions. These results are fully in line with recent developments in the Spanish labor market, where wage reaction to the strong increase in the unemployment rate was mild, especially in the first phase of the crisis initiated in 2008. Moreover, it should be noticed that composition effects exacerbate the weak procyclicality of wages in Spain in recessions since those groups with lower wage sensitiveness to the cycle, permanent workers and those with longer tenure, increase their share of total employment in downturns ${ }^{15}$.

Although identifying the sources of these rigidities is beyond the scope of this paper, these results would be in line with previous analyses, which have documented the presence of rigidities in the adjustment of labor costs in Spain ${ }^{16}$ along with very large employment volatility ${ }^{17}$. The Spanish labor market ${ }^{18}$ is characterized by a high degree of wage stickiness deriving from the main features of the collective bargaining system, where automatic extension of sectoral agreements extend their application to all firms and workers ${ }^{19}$ and where the dual structure of the Spanish labor market may exacerbate this wage rigidity (Bentolila and Dolado, 1994). Recent reforms approved since 2010 as a reaction to the strong deterioration of the labor market have tried to raise wage bargaining decentralization along with reducing the protection gap between permanent and temporary contracts. In particular, the prevalence of firm-level agreements was ensured and the conditions for opting-out clauses from sectoral agreements were eased, while employment protection for permanent contracts was decreased.

All in all, these recent changes should increase a firm's possibilities to adjust wages in the presence of adverse shocks, when, as the results of this paper has shown, downward wage rigidities additionally limit wage reaction to cyclical developments. This would contribute to reducing the firm's need to adjust their labor force. If proved successful, these measures would tend to increase wage elasticity to unemployment to a level more similar to those estimated in other European countries and then, hopefully, also contribute to decreasing the large employment/unemployment volatility which characterizes the Spanish labor market.

\section{Endnotes}

${ }^{1}$ It should be noticed that the rise in real wages is observed in 2008-2009 even when composition effects in employment are controlled. See Galan and Puente (2014).

${ }^{2}$ We have monthly information on wages and information on any change in the activity status of the worker, as the dataset collects information on the initial and expiry date of every contractual relationship of the worker included in the sample.

${ }^{3}$ Wage information coming from registers tends to be found more reliable than those obtained from household surveys due to large measurement errors and underreporting of wages in these later datasets.

${ }^{4}$ Using general CPI as a deflator.

${ }^{5}$ Around $12 \%$ of observations are found to be paid at the maximum level of the contributory base in our database. 
${ }^{6}$ Results are robust to different tenure grouping.

${ }^{7}$ Although workers' registers start from 1980, our sample begins in 1987 due to the construction of the group with more than six years of tenure.

${ }^{8}$ This approach also allows us to keep those individuals that do not work in two consecutive periods. A very similar specification is used in De la Roca (2014) and Carneiro et al. (2012), although in the latter case, the richness of their database allows them to include worker, job title and firm fixed effects.

${ }^{9} \mathrm{~A}$ lagged unemployment rate is normally used in the literature to take into account that wages are usually not able to respond contemporaneously to cyclical variations: since wage negotiations last for some time. Results are robust to different unemployment rate lags.

${ }^{10}$ There are a total of 108 periods from 1987:1 to 2013:4. Due to the number of coefficients that need to be estimated and the huge size of the database, results are based on a $20 \%$ random sample of the MCVL. Results are not sensitive to this threshold, though.

${ }^{11}$ Results are robust to using year-on-year variations of the unemployment rate.

${ }^{12}$ The estimation follows equations (2) and (3). A single estimation including all the four phases is done in both steps.

${ }^{13}$ See references in Table three in Pissarides (2009).

${ }^{14}$ Detailed results are available upon request.

${ }^{15}$ See Table 1.

${ }^{16}$ And with a high degree of price indexation. See, for instance Druant et al. (2012) for a comparative analysis with other European countries.

${ }^{17}$ In Ball et al. (2013), for instance, Spain is found as the country with the highest Okun's law coefficient among a large set of developed economies.

${ }^{18}$ See, for instance, Estrada et al. (2009)

${ }^{19}$ Independently of their participation in the negotiation. See Bentolila et al. (2010).

Competing interests

The IZA Journal of European Labor Studies is committed to the IZA Guiding Principles of Research Integrity. The authors declare that they have observed these principles.

\section{Acknowledgements}

We thank participants at the Banco de España seminar for insightful comments as well as those received from an anonymous referee. We also thank Dirección General de Ordenación de la Seguridad Social that kindly provided the Muestra Continua de Vidas Laborales (MCVL).

This paper is the sole responsibility of its authors and the views represented here do not necessarily reflect those of the Banco de España.

Responsible editor: Sara de la Rica

Received: 12 November 2014 Accepted: 30 March 2015

Published online: 26 June 2015

\section{References}

Ball L, Leigh D and Loungani P (2013) "Okun's Law: Fit at Fifty?" NBER Working Paper 18668, National Bureau of Economic Research.

Bentolila S, Izquierdo M and Jimeno JF (2010) "Negociación colectiva: la gran reforma pendiente", Papeles de Economía Española, num 124, pp 176-192.

Bentolila S, Dolado JJ (1994) Labour flexibility and wages: lessons from Spain". Econ Pol 18:53-99

Carneiro A, Guimaraes P, Portugal P (2012) Real wages and the business cycle: accounting for worker and firm heterogeneity". Am Econ J Macroecon 4(2):133-52

Cervini Pla, Silva MJI and Lopez A (2013) "The Heterogenous Cyclicality of Real Wages. Evidence from Wage Groups in Economic Expansions and Recessions", accessed at http://www.alde.es/encuentros/anteriores/xvieea/trabajos/c/pdf/ 296.pdf on April 11, 2015

De la Roca (2014) "Wage cyclicality: evidence from Spain using social security data" series. J Spanish Econ Assoc 5(2):173-195 
Devereux P (2001) The cyclicality of real wages within employer-employee matches". Ind Labor Relat Rev 54:835-850 Devereux PJ, Hart RA (2006) Real wage cyclicality of job stayers, within-company job movers, and between-company job movers. Ind Labor Relat Rev 60:105-119

Dickens WT, Goette L, Groshen EL, Holden S, Messina J, Schweitzer ME, Turunen J, Ward ME (2007) How wages change: micro evidence from the international wage flexibility project. J Econ Perspect 21:195-214

Druant M, Fabiani S, Lamo A, Sabbatini R, Kezdi G (2012) Firms' price and wage adjustment in Europe: survey evidence on nominal stickiness". Labour Econ 10(19(5)):772-782

Estrada A, Izquierdo M, Lacuesta A (2009) El funcionamiento del mercado de trabajo y el aumento del paro en España. Boletín Económico, Banco de España, pp 95-115

Galan S, Puente S (2014) Un análisis de los efectos composición sobre la evolución de los salarios. Boletín Económico, Banco de España, pp 57-61

Izquierdo M, Moral E and Urtasun A (2004) "Collective Bargaining in Spain: An Individual Data Analysis" Occasional Paper 0302, Banco de España

Martins PS (2007) Heterogeneity in real wage cyclicality. Scot J Polit Econ 54(5):684-698

Messina J, Duarte CF, Izquierdo M, Caju PD, Hansen NL (2010) "The incidence of nominal and real wage rigidity: an individual-based sectoral approach. J Eur Econ Assoc 8(2-3):487-496

Mitchell M, Wallace M, Warner J (1985) Real wages over the business cycle:some further evidence. South Econ J 51:1162-1173

Moulton BR (1986) Random group effects and the precision of regression estimates. J Economet 32(3):385-397

Peng F, and Siebert WS (2006): "Real Wage Cyclicality in Italy," Discussion Paper 2465, Institute for the Study of Labor (IZA)

Pissarides CA (2009) The unemployment volatility puzzle: is wage stickiness the answer? Econometrica 77(5):1339-69

Shin D (1994) Cyclicality of real wages among young men. Econ Lett 46:137-142

Shin D, Shin K (2008) Why are the wages of job stayers procyclical? Macroecon Dynam 12(01):1-21

Solon G, Barsky R, Parker J (1994) Measuring the cyclicality of real wages: how important is composition bias?

Q J Econ 109:1-25

Submit your manuscript to a SpringerOpen ${ }^{\odot}$ journal and benefit from:

- Convenient online submission

- Rigorous peer review

- Immediate publication on acceptance

- Open access: articles freely available online

- High visibility within the field

- Retaining the copyright to your article

Submit your next manuscript at $>$ springeropen.com 